\title{
TIPS JITU MEMULAI WIRAUSAHA PENDIDIKAN
}

\author{
Dea Ismani Yuliarti \\ Universitas Nahdlatul Ulama Sidoarjo
}

\section{Pengantar}

Pernahkah Anda memulai wirausaha pendidikan sekolah, tetapi Anda tidak yakin langkah apa yang harus Anda ambil, atau apakah itu bahkan menguntungkan?. Jangan khawatir, kamu tidak sendiri. Banyak orang skeptis sebelum mereka membuat bisnis sekolah. Lagipula, itu normal untuk melihat kisah sukses dan berpikir, "Ya, tetapi apakah itu akan berhasil untuk saya?". Anda tahu Anda memiliki keterampilan untuk mengajar, tetapi ada sedikit perasaan di hati Anda yang membuat Anda ragu-ragu. Jadi mari kita menenangkan pikiran Anda. Saat ini ada ribuan orang ingin belajar dari seorang guru seperti Anda. Mereka ingin mengambil kursus dari kenyamanan rumah mereka sendiri, dari seorang guru dengan pengetahuan di dalam parit, yang dapat memotong jargon kelas yang biasa.

Dunia wirausaha menjadi trendi karena tampilan kesuksesan yang menyilaukan (Purnomo et al., 2019). Dunia dan masyarakat membutuhkan kewirausahaan (Setyawati, Purnomo, Irawan, Tamyiz, \& Sutiksno, 2018). Bisnis sekolah juga merupakan salah satu bisnis termurah dan paling menguntungkan yang dapat Anda mulai. Untuk investasi kecil, Anda memiliki peluang untuk menumbuhkan penghasilan besar dan stabil.

\section{Langkah Nyata Wirausaha Pendidikan}

Pendidikan Indonesia membutuhkan peningkatan akses, mutu dan relevansi pendidikan untuk memberi manfaat membangun bagi pendidikan dan rakyat Indonesia (Irawan et al., 2018). Saya akan membahas dalam artikel ini mengapa ini merupakan ide bagus untuk memulai wirausaha pendidikan sekolah, dan bagaimana Anda dapat mengambil langkah pertama hari ini.

\section{Berpeluang}

Pendidikan adalah menyampaikan ilmu dan mentransformasi orang lain menjadi lebih baik (Fidiana, Istiana, Rosyidah, \& Purnomo, 2017). Penelitian tunjukkan industri pendidikan untuk mengidentifikasi berbagai peluang usaha kecil terkait pendidikan yang dapat Anda jelajahi. Dari bimbingan belajar dan penulisan kurikulum hingga menawarkan kelas etiket atau layanan pengeditan akademik, Anda dapat memulai berbagai bisnis 
yang mungkin terkait dengan pendidikan (Brookins, 2019). Siswa perlu memahami apa yang diketahui dan apa yang diminta untuk memiliki kemampuan menjawab (Suci et al., 2018).

\section{Pekerjakan Karyawan Berpengalaman}

Keberhasilan startup bisnis wirausaha pendidikan Anda bergantung pada orang-orang di belakang bisnis. Anda harus mempekerjakan karyawan berpengalaman yang akan menjalankan bisnis Anda secara profesional. Jika Anda seorang wirausahawan muda, jangan membuat kesalahan dengan mempekerjakan orang muda. Mereka mungkin menciptakan masalah yang bisa mahal untuk startup Anda. Karyawan yang berpengalaman bersama dengan tim manajerial yang efisien akan memandu Anda keluar dari masalah setiap kali Anda menghadapi tantangan (Ray, 2015). Prinsip pendidikan adalah sosial. Sebagai seorang guru, kita harus memiliki kepedulian sosial (Asitah, Usmawati, Rosyidah, \& Purnomo, 2017).

\section{Putuskan apa yang akan Anda ajarkan}

Anda mungkin sudah memberikan sedikit pemikiran ini, tetapi Anda harus benar-benar mengasah tentang mata pelajaran yang Anda rencanakan untuk dibuat. Bisnis pendidikan yang sukses harus didirikan pada kompetensi inti Anda - dengan kata lain, sesuatu yang dapat Anda buktikan bahwa Anda tahu banyak tentangnya. Asah keahlian yang Anda miliki yang berharga, berharga, dan yang paling diminati. Banyak dari ini akan tergantung pada kredensial Anda. Adalah satu hal untuk menyatakan bahwa Anda adalah seorang penulis atau penyanyi yang hebat, tetapi hal lain adalah menulis novel yang sukses atau menjadikannya sebagai seorang seniman atau pemain. Jika Anda telah mencapai tingkat keberhasilan dalam jalur karier, akan jauh lebih mudah untuk menjual proposisi nilai program studi Anda, karena Anda cenderung memiliki wawasan tentang cara mereplikasi kesuksesan itu. Jika Anda belum berhasil, saran yang Anda tawarkan adalah dugaan, dan kemungkinan akan menawarkan sedikit lebih banyak daripada yang dipikirkan orang lain secara online. Menawarkan kursus online membuka Anda ke banyak pasar potensial, tetapi Anda juga perlu tahu bahwa pasar belum ramai, dan kursus online adalah cara terbaik untuk mentransmisikan pengetahuan itu. Memutuskan subjek untuk bisnis pendidikan online Anda akan berarti melakukan penelitian tentang apa yang sudah tersedia dan apa yang populer. Jika pasar untuk topik Anda penuh, mungkin Anda dapat sedikit memutar topiknya dengan mengubah judul 
program, atau mengarahkannya ke target atau sasaran audiens yang sedikit berbeda (Eurostart Entreprises, 2015).

\section{Menganalisis Persaingan Pasar}

Sebelum memulai bisnis wirausaha layanan pendidikan, Anda harus menganalisis persaingan pasar Anda sehingga Anda mendapatkan gambaran tentang pasar. Menganalisis persaingan berarti menentukan berapa banyak pesaing yang Anda miliki di pasar. Dengan cara ini, Anda dapat memutuskan apa yang dilakukan pesaing Anda dan apa yang perlu Anda lakukan untuk menciptakan identitas Anda sendiri di pasar. Ingatlah bahwa sebuah bisnis pendidikan harus memiliki ide unik untuk membuatnya menonjol dari keramaian (Arya, 2019). Teknologi komputer telah menawarkan peluang baru dalam proses pembelajaran baik di ruang kelas, pembelajaran jarak jauh atau belajar mandiri (Simarmata et al., 2018).

\section{Pilih Keterampilan Inti Untuk Mengajar}

Manajemen adalah proses mengarahkan atau menjalankan bisnis, serta. sekelompok manajer atau direktur (Purnomo, Putri, \& Rosyidah, 2017). Itulah alasan siswa Anda mendaftar, dan mengapa mereka terus membayar untuk konten yang mungkin dapat mereka peroleh di tempat lain secara gratis. Mereka biasanya dua atau tiga keterampilan yang mereka tahu akan mereka bawa jika mereka tetap bersama Anda. Katakanlah Anda membuat sekolah bisnis untuk desainer grafis. Anda dapat membuat konten di sekitar ketiga "pilar" ini (Johnson, 2019):

- Penelitian: Cara menemukan klien potensial

- Penjangkauan: Cara menghubungi klien potensial secara efektif

- Penjualan: Bagaimana mengubah klien potensial menjadi yang membayar

Anda dapat menggunakannya untuk membantu merencanakan konten Anda, mendorong pemasaran Anda dan memastikan Anda memberikan hasil yang mereka cari. Patokan, semacam. Jika Anda tidak yakin akan hal ini, pikirkan tentang keinginan dan kebutuhan suku Anda. Apa hasil yang mereka cari, dan bagaimana Anda bisa membantu mereka mendapatkannya?. Ingin mempelajari semua ini secara lebih rinci? Lihat Sekolah Bisnis Video baru milik Uscreen! Ini akan memandu Anda melalui seluruh proses peluncuran bisnis video online dalam bentuk apa pun dari awal hingga selesai (Johnson, 2019). Hasil penelitian menunjukkan bahwa penerapan pembelajaran multimedia dapat meningkatkan prestasi siswa; 
dan tes menunjukkan bahwa prestasi belajar siswa kelas belajar multimedia lebih baik daripada siswa kelas konvensional (Iskandar, Rizal, Kurniasih, Sutiksno, \& Purnomo, 2018). Implementasi teknologi pembelajaran adalah salah satu cara yang diperlukan untuk menunjukkan kompetensi lulusan yang berkualitas (Sudrajat et al., 2019).

\section{Kesimpulan}

Memulai wirausaha pendidikan dilakukan dengan tahapan yakni berpeluang dan pekerjakan karyawan berpengalaman, putuskan apa yang akan anda ajarkan, menganalisis persaingan pasar, dan pilih keterampilan inti untuk mengajar.

\section{References}

Arya, N. (2019). Things to Consider While Starting an Educational Services Business. Retrieved December 3, 2019, from https://www.franchiseindia.com/education/things-to-consider-whilestarting-an-educational-services-business.12980

Asitah, N., Usmawati, D. Z., Rosyidah, E., \& Purnomo, A. (2017). MI Hasyim Asy' ari Ilmu Harus Terus Mengarus. In Wirausaha Pendidikan Indonesia (Jilid 2). Sidoarjo: UNUSIDA Press.

Brookins, M. (2019). How to Start an Education Related Small Business.

Retrieved December 1, 2019, from https://smallbusiness.chron.com/starteducation-related-small-business-2239.html

Eurostart Entreprises. (2015). How to start an online education business.

Retrieved December 2, 2019, from

https://www.eurostartentreprises.com/business-advice/item/194-how-

to-start-an-online-education-business

Fidiana, W., Istiana, Z., Rosyidah, E., \& Purnomo, A. (2017). MINU Waru 2

Insan Berkilau Cahaya Manfaat. In Wirausaha Pendidikan Indonesia (Jilid

4). Sidoarjo: UNUSIDA Press.

Irawan, D. E., Purnomo, A., Sutiksno, D. U., Abraham, J., Alamsyah, A., Saputra, D. H., $\cdots$ Rosyidah, E. (2018). Kajian Pendidikan Tinggi IDRI untuk DPR RI dan Ristek Dikti 2018. Bandung: ITB Press.

Iskandar, A., Rizal, M., Kurniasih, N., Sutiksno, D. U., \& Purnomo, A. (2018). The Effects of Multimedia Learning on Students Achievement in Terms of Cognitive Test Results. Journal of Physics: Conference Series, 1114(1), 012019. https://doi.org/10.1088/1742-6596/1114/1/012019

Johnson, J. (2019). How to Start a Profitable Online School in 5 Easy Steps. Retrieved December 5, 2019, from https://www.uscreen.tv/blog/how-tostart-create-online-school/

Purnomo, A., Asitah, N., Rosyidah, E., Septianto, A., Daryanti, M. D., \& Firdaus, M. (2019). Generasi Z sebagai Generasi Wirausaha. 
https://doi.org/10.31227/osf.io/4m7kz

Purnomo, A., Putri, R. A., \& Rosyidah, E. (2017). Kamus Manajemen Sumber

Daya Manusia. Sidoarjo: UNUSIDA Press.

Ray, H. (2015). 5 Easy Steps to Successfully Launch an Educational Startup.

Retrieved December 4, 2019, from https://www.designhill.com/designblog/easy-steps-to-successfully-launch-an-educational-startup/

Setyawati, I., Purnomo, A., Irawan, D. E., Tamyiz, M., \& Sutiksno, D. U. (2018). A

Visual Trend of Literature on Ecopreneurship Research Overviewed within

The Last two Decades. Journal of Entrepreneurship Education, 21(4), 1-7.

Retrieved from https://www.abacademies.org/articles/a-visual-trend-of-

literature-on-ecopreneurship-research-overviewed-within-the-last-two-

decades-7468.html

Simarmata, J., Dharma, M., Putra Nasution, T., Manurung, R. T., Lubis, M. A., Kurniasih, N., ‥ Rahim, R. (2018). Prototype Application Multimedia Learning for Teaching Basic English. International Journal of Engineering \& Technology, 714(2), 264-266.

https://doi.org/10.14419/ijet.v7i2.12.14689

Suci, S. H. A., Rosyidah, E., Asitah, N., Aini, N., Murni, A. W., Anam, F., ..

Kuraesin, A. D. (2018). Learning from Picture and Picture Action

Research : Enhancement of Counting Ability on Division of Numbers for

Primary School Students. Journal of Physics: Conference Series, 1114(1),

012044. https://doi.org/10.1088/1742-6596/1114/1/012044

Sudrajat, D., Achdisty, M., Kurniasih, N., Roslina, Parwito, Mulyati, S., ‥ Sallu,

S. (2019). The Implementation of Innovation in Educational Technology to Improve The Quality of Website Learning in Industrial Revolution Era 4.0 Using Waterfall Method. Journal of Physics: Conference Series, 1364, 012044. https://doi.org/10.1088/1742-6596/1364/1/012044 